Journal of Animal and Feed Sciences, 7, 1998, $333 \quad 352$

\title{
Protein turnover, body composition, muscle characteristics, and blood hormones in response to different direction of growth selection in mice
}

\author{
Ruthild Schadereit', Charlotte Rehfeldt', K. Krawielitzki' ${ }^{2}$, \\ Monika Klein', Ellen Kanitz ${ }^{1}$ and S. Kuhla ${ }^{1}$
}

\author{
'Research Institute for the Biology of Farm Animals, \\ Department of Nutritional Physiology , Oskar Kellner" \\ 18059 Rostock, Germany \\ ${ }^{2}$ Institute for Applied Agricultural Ecology, University of Rostock \\ Justus-von-Liebig-Weg 2, 18059 Rostock, Germany
}

(Received 10 April 1998; accepted 24 June 1998)

\begin{abstract}
Whole body protein turnover and tissue traits were studied in growing male mice long-term selected (78 generations) for carcass protein mass (DU-6P, protein line), for body weight (DU-6, growth line) or for an index combining body weight and treadmill performance (DU-6+LB, growth+fitness line) and in the unselected randomly bred control (DU-Ks). For the estimation of protein turnover data six mice of each line were housed individually in metabolic cages and were fed ad libitum a commercial stock diet (crude protein $268 \mathrm{~g}$, gross energy $19 \mathrm{MJ} / \mathrm{kg} \mathrm{DM}$ ). At the end of the experiment body weight of all selected mice was about twice that of the controls. Fractional rates of protcin synthesis (scaled to the corresponding body protein pools) were significantly higher in selected mice than in controls, but were not significantly different between the protein and growth line in contrast to the protein deposition rates. Chemical body composition was changed in dependence on selection traits. In the growth line body fat content was highest at the expense of protein content; in the protein line the proportion of lean body mass (muscle protein) was highest. This is supported by results of a previous experiment (generation 68) on 60-days old mice showing an enlargement of cross sectional area of the EDL muscle. The number of capillaries per fibre as indicator for nutrient and oxygen supply of the muscle it as adequately increased with the enlargement of muscle cross section in all selection lines, but it was even doubled in the growth+fitness line. No significant alterations in blood thyroid hormone levels $\left(\mathrm{T}_{3}, \mathrm{~T}_{4}\right)$ or in free glutamine content of muscles extracts were observed in response to selection. Plasma IGF-I levels were higher in selected lines than in controls.
\end{abstract}

KEY WORDS: body composition, protein synthesis, ${ }^{15} \mathrm{~N}$, end-product method, tracer technique, IGF-I, thyroid hormones, mice 


\section{INTRODUCTION}

Protein accretion in animals depends on genotypc, age, activity and nutritional status. These determinants exert at least some of their effects via hormonal mechanisms. Relationships between blood hormone levels (thyroid hormons, insulin and (GF-I) and muscle protein turnover rates were observed in rats fed on different protein levels (Jepson et al., 1988a; Millward, 1989). To explore whether selection-linked relationships exist between blood hormone levels and parameters of protein metabolism long-term selected lines of mice were used as a model. These mouse lines exhibit significantly different phenotypes with regard to growth and chemical body composition due to long-term selection for high body wcight or high carcass protcin content (Bünger et al., 1985, 1987). In the present studies these lines were characterized concerning growth parameters, protein turnover and some blood hormones. Additionally, histological/histochemical data of muscles from mice of generation 68 of selection were collected and illustrated in dependence on the used selection traits, since marked genctic relations were observed previously between muscle structure and growth characteristics (Rchfeldt ct al., 1989).

\section{MATERIAL AND METHODS}

\section{Animals and diets}

The experimental mouse lines were established from an outbred base population (F7t:DU) bred from 4 outbred (NMRI, Han:NMR, CFW, CF1) and 4 inbred strains (CBA, AB, C57Bl, XVII), (Bünger ct al., 1985; Schüler, 1985). These lines selected on day 42 of age for 78 generations were:

DU-Ks, randomly bred control, unselected (control line),

DU-6P, selected for high carcass protein content (protein line),

DU-6, selected for high body weight (growth line),

DU-6+LB, selected for an index combining body weight and physical fitness (growth + fitness line).

The experiment was conducted with growing male mice from cach line. Throughout the trials, the mice were housed at a constant temperature $\left(22^{\circ} \mathrm{C}\right)$ and

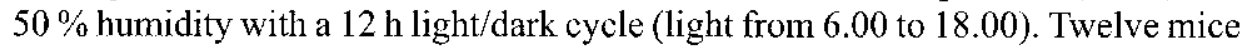
per line (Generation 78) were weaned at 21 days of age and divided randomly into 2 subgroups. Six mice were adapted to single housing in screen-bottom metabolic cages (diameter $21 \mathrm{~cm}$, height $12 \mathrm{~cm}, 3$-floor battcry, E. Becker and $\mathrm{Co} \mathrm{GmbH}$, Castrop-Rauxel, Germany) immediately after weaning (subgroup 1, used for $\mathrm{N}$ balance studies and estimation of protein turnover data). The remaining 6 mice 
(subgroup 2, used for body analyses) were housed singly in polystyrene breeding cagcs (13 cm wide x $15 \mathrm{~cm}$ height) throughout the experiment. All mice were fed ad libitum with a commercial pelleted standard diet (Altromin 1310, Altromin international, Lage/Lippe, Germany; see Table 1) with free access to water.

TABLE 1

Nutrient composition of the Altromin stock diet, $\mathrm{g} / \mathrm{kg} \mathrm{DM}$

\begin{tabular}{lrlr}
\hline Crude protein & 268 & Lysine & 14.2 \\
Crude fibre & 42 & Mcthioninc + Cystcine & 10.5 \\
Crude fat & 61 & Threonine & 9.9 \\
Ash & 69 & Arginine & 16.3 \\
Gross energy (MJ) & 19.1 & & \\
Protein encrgy as percentage of gross energy & 35 & & \\
\hline
\end{tabular}

The metabolism experiment with subgroup 1 consisted of three subperiods: a 5-days preperiod for adaption of mice to experimental conditions, a 5-days main period for estimation of nitrogen $(\mathrm{N})$ balance (26 days of age at start) and a 1-day tracer period for measurement of whole body protein synthesis. During the $\mathrm{N}$ balance period urine and faces were collected immediately in sulphuric acid (5\%) and homogenized before $\mathrm{N}$ analysis of aliquots.

$\mathrm{A}^{15} \mathrm{~N}$-labelled amino acid (AA) mixture with an similar AA composition as the stock diet was used (all AA with the exception of proline, cysteine and tyrosine were ${ }^{15} \mathrm{~N}$-labelled, average enrichment of the mixture 84 atom $\%$ excess) for a 1 -day tracer cxperiment. This mixture was dissolved in water before application of $150-200 \mu 1$ of the solution by stomach tube to each animal $\left(35-41 \mathrm{mg}{ }^{15} \mathrm{~N} / \mathrm{kg}\right.$ body weight). At the end of the experiment ( $33 \mathrm{~d}$ of age) mice of both subgroups werc ancsthesized with urethane and killed by terminal bleeding (cardiac puncture). Blood was stored on ice before centrifugation at $4^{\circ} \mathrm{C}$ at $1450 \mathrm{x}$ g. For the estimation of insulin-like growth factor-I (IGF-I) concentrations EDTA plasma was used. The thyroid hormone $\left(\mathrm{T}_{3}, \mathrm{~T}_{4}\right)$ levels were measured in blood serum. Bodies of subgroup I were dissected into 3 fractions (eviscerated carcass, organs and skin + head+paws) for the estimation of nitrogen distribution. Plantaris and tibialis muscles of the right hindlimb were analyzed for free glutamine (GLN) content. Bodies of subgroup 2 were used for the estimation of the chemical body composition after the removal of gut contents. All samples were preserved at $-20^{\circ} \mathrm{C}$ until analysis. Tissue fractions and carcasses were autoclaved, homogenized and freezedrycd before analysis of the chemical composition (protein, fat, ash).

\section{Analytical methods}

Tissue water content was measured by freeze-drying the homogenates until weight constance and by terminal drying at $105^{\circ} \mathrm{C}$. Nitrogen analysis of all sam- 
ples was performed by the semimicro Kjeldahl method; ${ }^{15} \mathrm{~N}$ excess was estimated by emission spectrometry, using the ${ }^{15} \mathrm{~N}$-analyzer NOI-6e (FAN Fischer Analysen Instrumente $\mathrm{GmbH}$, Leipzig, Germany). Ash and fat content of food and carcass samples were determined with conventional methods (ash: $7 \mathrm{~h}$ ashing at $600^{\circ} \mathrm{C}$; fat: Soxhlet method without hydrolysis using petrol ether as solvent, Naumann and Bassler, 1993). The gross energy content of the diets was determined with an adiabatic bomb calorimeter (C 400, Janke and Kunkel, Staufen, Germany).

GLN concentration in the muscles was analyzed according to a modified method of Jepson et al. (1988b) on aliquots of muscle sulphursalicylic acid (SSA) extracts by ion-exchange chromatography using the physiological run and shortened program of the AA analyzer Biochrom 20 (Pharmacia-Biotech Europe GmbH, Freiburg, Germany). Plasma IGF-I concentration was estimated after acid-alcohol extraction using a ${ }^{125} \mathrm{~J}$-RIA (Nichols Institute, Diagnostica $\mathrm{GmbH}$, Bad Nauhcim, Germany). Thyroxine $\left(\mathrm{T}_{4}\right)$ and 3,5,3' -triiodothyronine $\left(\mathrm{T}_{3}\right)$ levels were measured by a ${ }^{125} \mathrm{~J}$-RIA (RIA mat ${ }^{\circledR}$, Byk-Sangtcc Diagnostica $\mathrm{GmbH}$ and Co, Dietzenbach, Germany).

\section{Muscle fibre characteristics}

To support the results on protein metabolism and body composition the findings on muscle structure characteristics of these mouse lines cstimated in a previous experiment (generation 68) were included. These mice were killed by cervical dislocation at 60 days of age and the lower leg muscle group was prepared from the bone. Serial transverse sections $(10 \mu \mathrm{m})$ from the midbclly of the EDL (M. extensor digitorum longus) were cut in a cryostat $\left(-20^{\circ} \mathrm{C}\right)$ mounted on slides and stained by NADH-tetrazolium-reductase (Novikoff et al., 1961) for fibre types, alkaline phosphatase for capillaries (Gomori, 1952, described by Spannhof, 1967) or by haemalum-eosin for nuclei (Romeis, 1989), respectively.

Projected microscopic images of muscle cross section were used to determine EDL cross sectional area by planimetry and to count total muscle fibre number. Muscle fibre cross sectional area was calculated by dividing the EDL cross sectional area by the total muscle fibre number. Muscle fibre type frequencies of red, intermediate and white fibres were measured on the basis of about 350 fibres in the middle of the cross section by the semiautomatic muscle fibre analyzer "MBA2" (Beyersdorfer et al., 1985). The numbers of nuclei or capillaries were counted at a $400 \times$ magnification by an ocular grid ( 8 times) corresponding to an area of $0.5 \mathrm{~mm}$, containing about 400 fibres.

\section{Calculations}

The protein content of tissue was calculated by multiplying the nitrogen $(\mathrm{N})$ content by 6.25 . Estimation of the whole body protein synthesis rate was based on 
the measurement of the cumulative renal excretion of the label (end product method) over a $24-\mathrm{h}$ period after a single ${ }^{15} \mathrm{~N}$ dose. The protein breakdown rate was subsequently calculated as the difference between the synthesis rate and protein accretion rate measured as nitrogen balance. The kinetic parameters of the protein metabolism were calculated using a three-compartment model, and the CADEMO computer program (Rasch et al., 1987, as described by Krawielitzki et al., 1989). Relations between traits were determined by simple linear correlation coefficients.

Data of the metabolism experiment are presented as means ( \pm SD) for each group. Effects were evaluated by one-way ANOVA, and Tukey HSD test for uncqual $\mathrm{n}$ using the Statgraphics 5.0 (1995) Package. Data of muscle structure characteristics were evaluated by the GLM procedure of the SAS System (SAS 6.12 Package).

\section{RESULTS}

\section{Growth performance}

Feed intake of selected mice was about 1.5 times higher, daily gain (with the exception of line DU-6+LB) and body weight were about 2 times higher than in controls at the same chronological age (Table 2 ). Feed intake of both subgroups during the balance period as well as body weights at the end of the experiment

TABLE 2

$\mathrm{N}$ balance data of mice selected for different growth traits over 78 generations and of the control line from day 26 to 31 of age

\begin{tabular}{|c|c|c|c|c|}
\hline Parameter/line & $\begin{array}{l}\text { Control } \\
\text { DU-Ks }\end{array}$ & $\begin{array}{c}\text { Protein line } \\
\text { DU-6P }\end{array}$ & $\begin{array}{l}\text { Growth line } \\
\text { DU-6 }\end{array}$ & $\begin{array}{c}\text { Growth+fitness line } \\
\text { DU-6+LB }\end{array}$ \\
\hline No. of animals & 6 & 6 & 6 & 6 \\
\hline Mean body weight, $\mathrm{g}$ & $22.2+1.1^{\mathrm{a}}$ & $37.5+3.4^{\mathrm{b}}$ & $36.9+2.1^{b}$ & $35.5 \pm 1.3^{b}$ \\
\hline Feed intake, g DM/d & $4.3 \pm 0.3^{a}$ & $6.9 \pm 0.2^{\mathrm{b}}$ & $5.8 \pm 0.2^{\circ}$ & $6.7 \pm 0.3^{b}$ \\
\hline Daily gain, g/d & $1.2 \pm 0.2^{\mathrm{a}}$ & $1.9 \pm 0.2^{b}$ & $2.2 \pm 0.4^{\mathrm{b}}$ & $1.4 \pm 0.4^{\mathrm{a}}$ \\
\hline $\mathrm{N}$ intake, $\mathrm{mg} / \mathrm{d}$ & $175 \pm 14^{a}$ & $284 \pm 9^{b}$ & $275 \pm 10^{b}$ & $249 \pm 7^{c}$ \\
\hline \multicolumn{5}{|l|}{$\mathrm{N}$ excretion, $\mathrm{mg} / \mathrm{d}$} \\
\hline urine & $84 \pm 11^{2}$ & $127 \pm 9^{b}$ & $147 \pm 6^{c}$ & $130 \pm 6^{6}$ \\
\hline faeces & $39 \pm 3^{a}$ & $70 \pm 3^{b}$ & $61 \pm 5^{c}$ & $53 \pm 4^{c}$ \\
\hline $\mathrm{N}$ accretion, mg/d & $52 \pm 3^{a}$ & $87 \pm 8^{b}$ & $67 \pm 9^{c}$ & $66 \pm 5^{\mathrm{c}}$ \\
\hline $\mathrm{N}$ accretion $/ \mathrm{N}$ intake, $\%$ & $29.2 \pm 1.9^{\mathrm{a}}$ & $30.6 \pm 2.5^{a}$ & $24.3 \pm 2.7^{b}$ & $26.6 \pm 1.5^{\mathrm{ab}}$ \\
\hline
\end{tabular}

values are means and SD

$\mathrm{a}, \mathrm{b}-$ significant differences between the groups are indicated by different letters $(\mathrm{P}<0.05)$ 
were nearly similar within the limits of variation (data not shown). At almost equal $\mathrm{N}$ intakes per day mice of the protein line accreted significantly more $\mathrm{N}$ per day and utilized significantly morc $\mathrm{N}$ for accretion than those of the growth line as evidenced by a lower urinary $\mathrm{N}$ excretion (46 and $54 \%$ of intakc in DU-6P and DU-6, respectively). $\mathrm{N}$ intake and daily gain of index selected mice was lower than in the other selection lines, and $\mathrm{N}$ accretion was intermediate. Apparent $\mathrm{N}$ digestibility was not different between the lines and varied between 76 and $78 \%$.

\section{Body composition}

At the end of the experiment (33 days of age) body weights of selected mice were nearly doubled in comparison to controls. In animals selected for high body weight a decreased protein, ash and water content and an increased fat percentage in the body was observed in comparison to the other lines (Table 3). Body composition was almost unchanged in mice selected for protein mass or for an index combining growth and treadmill endurance. Highest proportion of lean body mass (LBM, skinned eviscerated body without head, legs and tail) was determined in the protein line. N proportions of LBM (as a percentage of total body $\mathrm{N}$ ) were lower in all lines, but were in the same range as $\operatorname{LBM}(36.0,41.5,38.1$ and $38.4 \%$ in DU-Ks, DU-6P, DU-6 and DU-6+LB, respectively, data not shown).

In response to selection changes in relative organ weights (expressed as percentage of body wcight) were obscrved. The deviations from unselected controls illustrate Figure 1.

TABLE 3

Body composition of mice selected for different growth traits over 78 generations and of the control line at 33 days of age

\begin{tabular}{lcccc}
\hline Parameter/line & $\begin{array}{c}\text { Control } \\
\text { DU-Ks }\end{array}$ & $\begin{array}{c}\text { Protein line } \\
\text { DU-6P }\end{array}$ & \multicolumn{2}{c}{$\begin{array}{c}\text { Growth line Growth+fitness line } \\
\text { DU-6 }\end{array}$} \\
\hline No. of animals & 6 & 6 & 6 & DU-6+LB \\
Final body weight, g & $26.1 \pm 1.6^{\mathrm{a}}$ & $42.9 \pm 2.1^{\mathrm{b}}$ & $45.9 \pm 3.2^{\mathrm{b}}$ & $39.2 \pm 3.0^{\mathrm{b}}$ \\
Dry matter, DM, \% & $29.8 \pm 0.3^{\mathrm{a}}$ & $29.9 \pm 0.4^{\mathrm{a}}$ & $30.6 \pm 0.6^{\mathrm{a}}$ & $28.9 \pm 0.5^{\mathrm{a}}$ \\
Protein, \% DM & $61.3 \pm 1.3^{\mathrm{a}}$ & $63.2 \pm 0.9^{\mathrm{a}}$ & $53.8 \pm 0.9^{\mathrm{b}}$ & $61.1 \pm 2.2^{\mathrm{a}}$ \\
Fat, \% DM & $29.0 \pm 1.6^{\mathrm{a}}$ & $27.3 \pm 1.1^{\mathrm{a}}$ & $37.9 \pm 0.8^{\mathrm{b}}$ & $29.6 \pm 2.3^{\mathrm{a}}$ \\
Ash, \% DM & $9.7 \pm 0.3^{\mathrm{a}}$ & $9.5 \pm 0.6^{\mathrm{a}}$ & $8.3 \pm 0.4^{\mathrm{b}}$ & $9.3 \pm 0.2^{\mathrm{a}}$ \\
Lean body mass, & & & & \\
LBM, \% of BW & $40.5 \pm 1.2^{\mathrm{a}}$ & $43.5 \pm 0.6^{\mathrm{b}}$ & $40.8 \pm 1.2^{\mathrm{a}}$ & $41.0 \pm 0.6^{\mathrm{a}}$ \\
\hline
\end{tabular}

values are means and SD

a, b - significant differences between the groups are indicated by different letters $(P<0.05)$ 


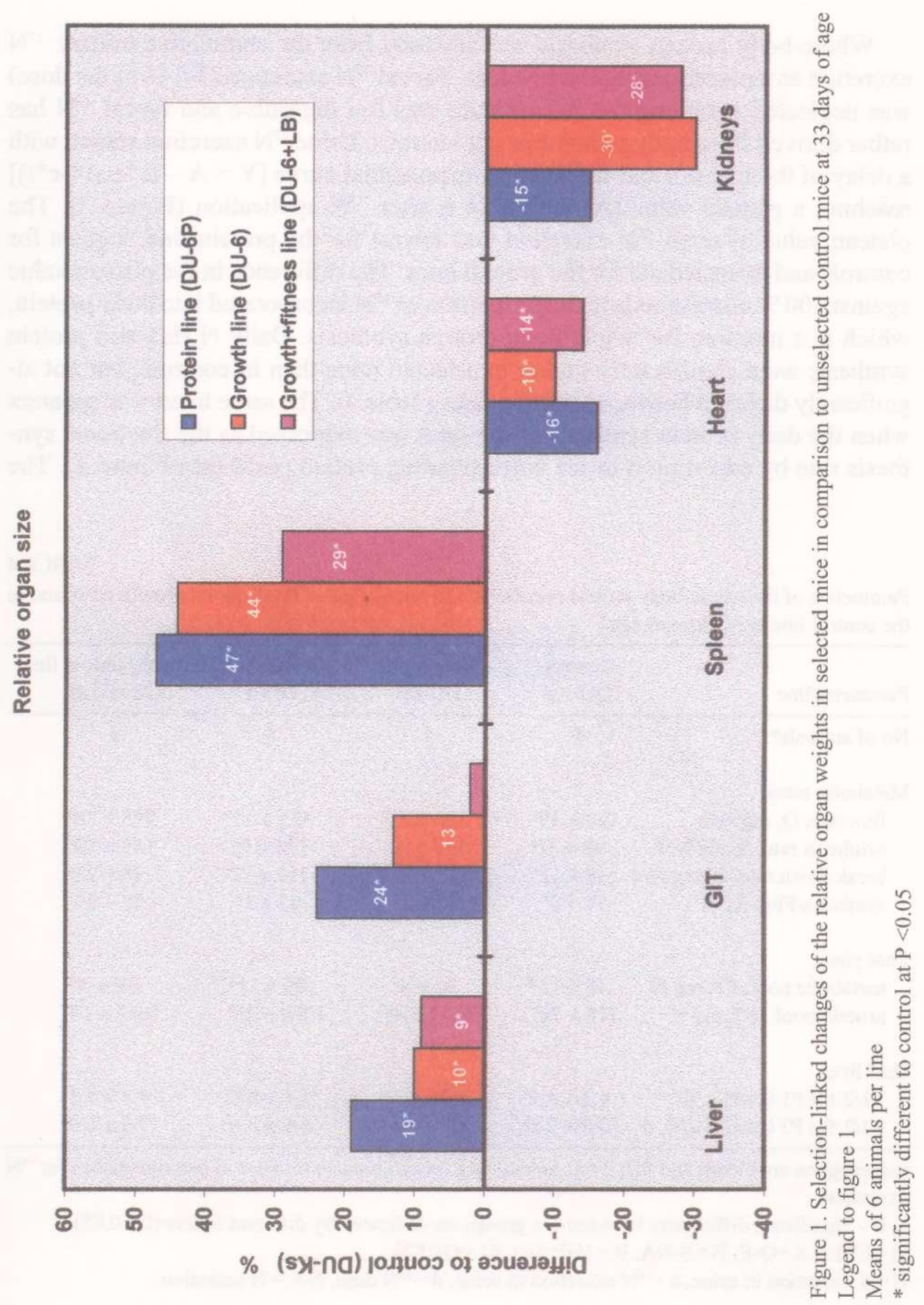




\section{Protein turnover data}

Wholc-body protein synthesis was assessed from the cumulative urinary ${ }^{15} \mathrm{~N}$ excretion as a percentage of the ${ }^{15} \mathrm{~N}$ dose. Faecal ${ }^{15} \mathrm{~N}$ excretion (3-6\% of the dose) was neglected assuming the AA mixture was full digestible and faccal ${ }^{15} \mathrm{~N}$ has rather derived from body proteins or gut microbs. Urine ${ }^{15} \mathrm{~N}$ excretion started with a delay of 0.4 to $0.6 \mathrm{~h}$ and followed an exponential curve [Y $=\mathrm{A}-\mathrm{B}^{*} \exp \left(-\mathrm{c}^{*} \mathrm{t}\right)$ ] reaching a plateau value (A) within $24 \mathrm{~h}$ after ${ }^{15} \mathrm{~N}$ application (Figure 2). The plateau value of renal ${ }^{15} \mathrm{~N}$ excretion was lowest for the protein line, highest for controls and intermediate for the growth lines. The difference in the plateau value against $100 \%$ corresponds to the proportion of ${ }^{15} \mathrm{~N}$ incorporated into body protein, which is a measure for whole body protein synthesis. Daily $\mathrm{N}$ flux and protein synthesis were significantly higher in selected mice than in controls, but not significantly different between selection lines (Table 4). The same trend was apparent when the daily protein synthesis of the lines was expressed as the fractional synthesis rate by adjusting it to the corresponding protein pools (see Figure 3 ). The

TABLE 4

Parameters of the whole body protein metabolism in mice selected for different growth traits and in the control line at 31 days of age

\begin{tabular}{|c|c|c|c|c|}
\hline Parameter/line & $\begin{array}{l}\text { Control } \\
\text { DU-Ks }\end{array}$ & $\begin{array}{c}\text { Protein line } \\
\text { DU-6P }\end{array}$ & $\begin{array}{c}\text { Growth line } \\
\text { DU-6 }\end{array}$ & $\begin{array}{c}\text { Growth }+ \text { fitness line } \\
\text { DU }-6+\text { LB }\end{array}$ \\
\hline No of animals* & 5 & 5 & 5 & 5 \\
\hline \multicolumn{5}{|l|}{ Metabolic rates } \\
\hline flux rate, $\mathrm{Q}, \mathrm{mg} \mathrm{N} / \mathrm{d}$ & $182 \pm 19^{a}$ & $326 \pm 27^{b}$ & $325 \pm 17^{\mathrm{b}}$ & $295 \pm 20^{b}$ \\
\hline synthesis rate, $\mathrm{S}, \mathrm{mg} \mathrm{N} / \mathrm{d}$ & $98 \pm 11^{a}$ & $199 \pm 18^{b}$ & $178 \pm 9^{b}$ & $165 \pm 20^{b}$ \\
\hline break down rate, $B, \mathrm{mg} \mathrm{N} / \mathrm{d}$ & $46 \pm 12^{a}$ & $112 \pm 22^{b}$ & $111 \pm 10^{\mathrm{b}}$ & $96 \pm 23^{b}$ \\
\hline synthesis/Flux R, \% & $54 \pm 3^{a}$ & $61 \pm 1^{\mathrm{b}}$ & $55 \pm 1^{\mathrm{a}}$ & $55 \pm 3^{\mathrm{a}}$ \\
\hline \multicolumn{5}{|l|}{ Pool sizes } \\
\hline metabolic pool, P1, mg N & $46 \pm 12^{a b}$ & $36 \pm 6^{a}$ & $36 \pm 11^{a}$ & $59 \pm 8^{b}$ \\
\hline protein pool , P2, mg N & $718 \pm 28^{a}$ & $1077 \pm 47^{b}$ & $1009 \pm 29^{b}$ & $1055 \pm 63^{b}$ \\
\hline \multicolumn{5}{|l|}{ Half lives } \\
\hline $\mathrm{T} 1 / 2$ for $\mathrm{P} 10.693 / \mathrm{c}, \mathrm{h}$ & $4.2 \pm 0.9^{\mathrm{a}}$ & $3.0 \pm 0.7^{\mathrm{a}}$ & $3.4 \pm 0.6^{\mathrm{a}}$ & $3.4 \pm 0.7^{\mathrm{a}}$ \\
\hline $\mathrm{Tl} / 2$ for $\mathrm{P} 20.693^{*} \mathrm{P} 2 / \mathrm{B}, \mathrm{d}$ & $10.8 \pm 2.5^{\mathrm{a}}$ & $6.7 \pm 0.6^{b}$ & $6.3 \pm 0.6^{b}$ & $7.6 \pm 0.9^{b}$ \\
\hline
\end{tabular}

values given are means and $\mathrm{SD} ;{ }^{*}$ one animal/line was eliminated because of extreme values for ${ }^{15} \mathrm{~N}$ excretion

a, $b-$ significant differences between the groups are indicated by different letters $(P<0.05)$

$\mathrm{Q}=\mathrm{E}^{*} \mathrm{~d} / \mathrm{e}, \mathrm{S}=\mathrm{Q}-\mathrm{E}, \mathrm{B}=\mathrm{S}-\mathrm{NA}, \mathrm{R}=100 * \mathrm{~S} / \mathrm{Q}, \mathrm{P} 1=\mathrm{Q} / \mathrm{c}^{*} 24$

$\mathrm{E}=\mathrm{N}$ excretion in urine, $\mathrm{e}={ }^{15} \mathrm{~N}$ excretion in urine, $\mathrm{d}={ }^{15} \mathrm{~N}$ dose, $\mathrm{NA}=\mathrm{N}$ accretion 


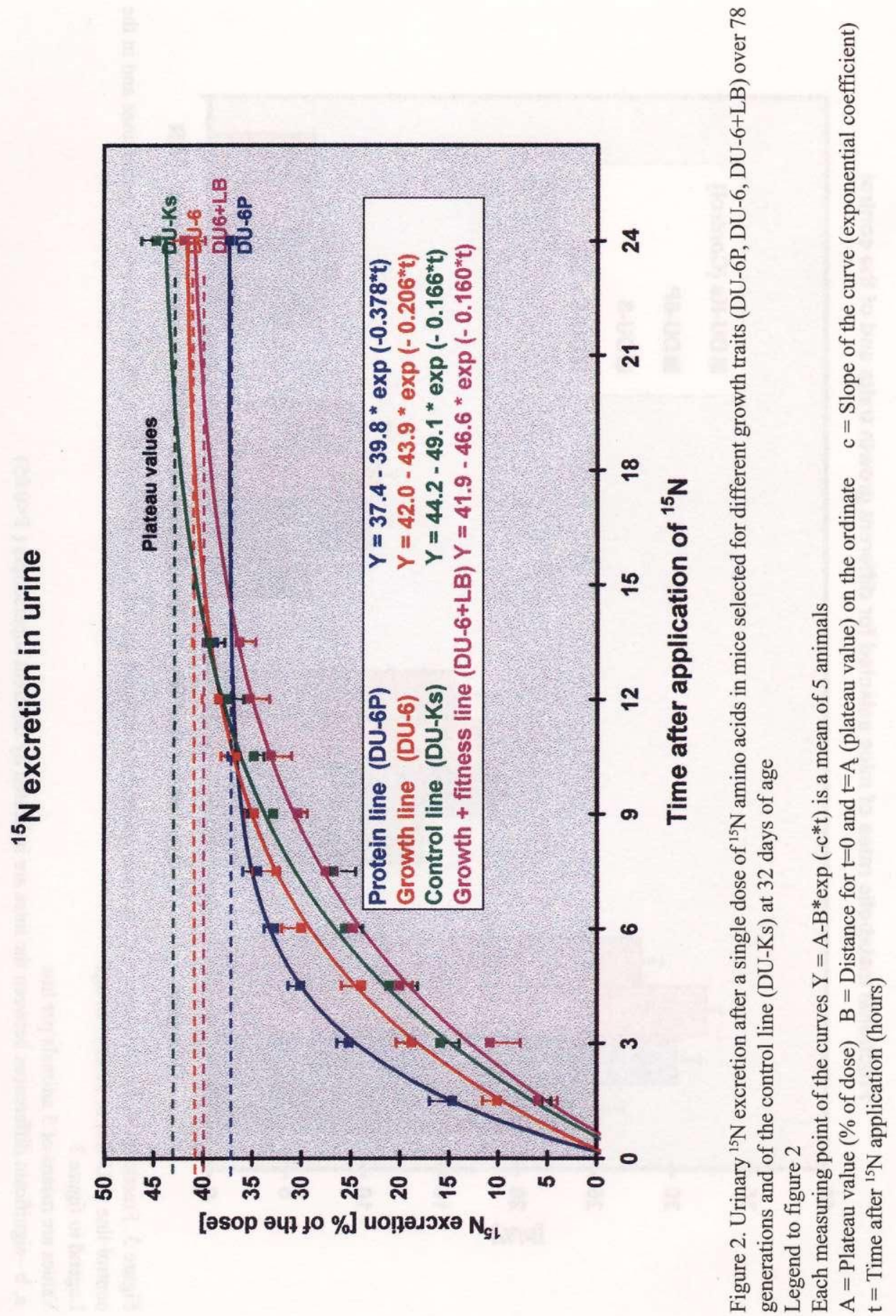




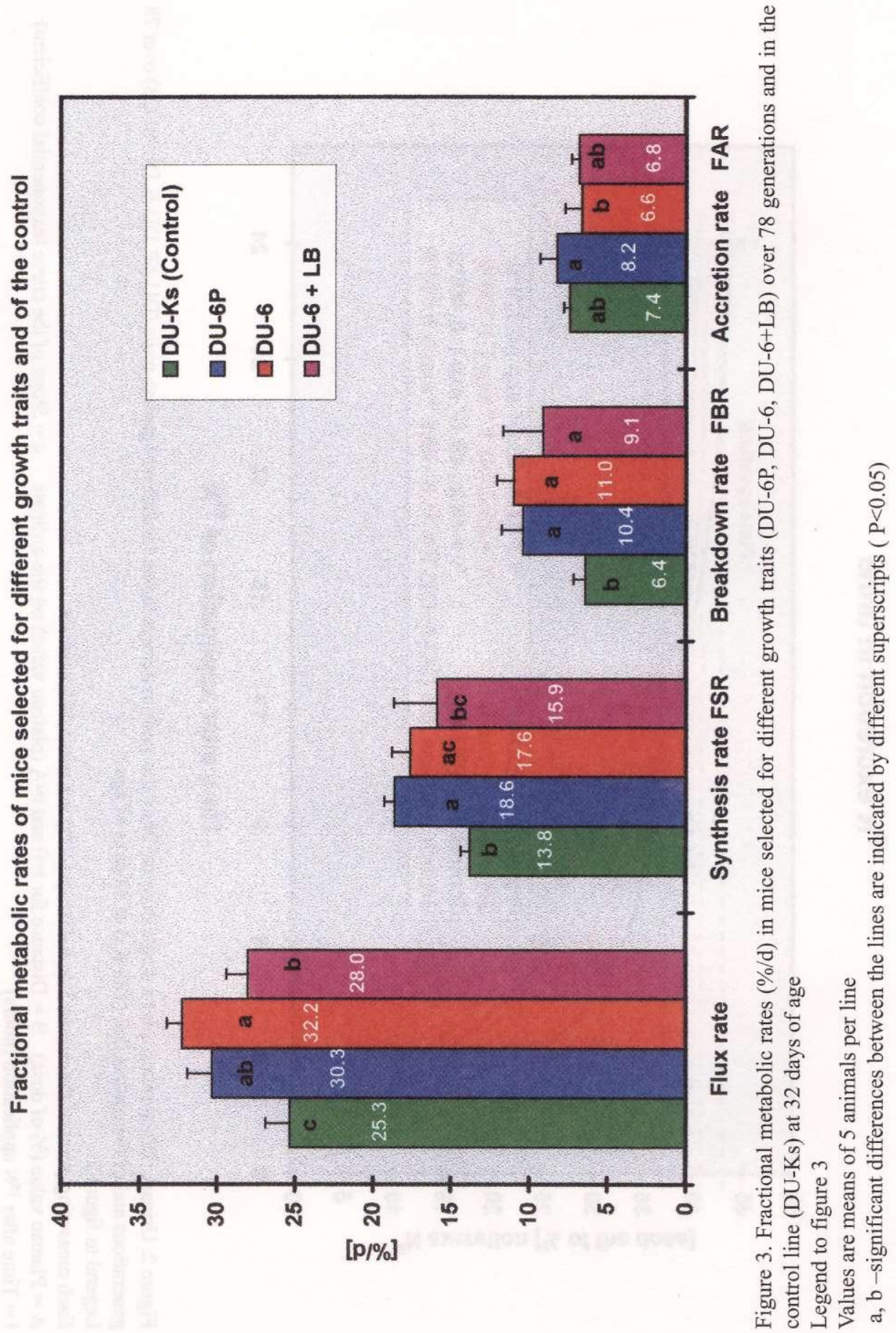


difference in the fractional rate of protein accretion between the protein line $(8.2 \pm 0.7 \% / \mathrm{d})$ and the growth lines $(6.6 \pm 0.7$ and $6.8 \pm 0.4 \% / \mathrm{d}$ in DU-6 and DU-6+LB, respectively) was still significant.

Protein turnover rates of the growth+fitness line showed a tendency towards lower values than in the other both selection lines. $\mathrm{N}$ reutilization for protein synthesis indicated by the ratio of protein-synthesis/flux was significantly higher in the protein line than in the other selection lines. However, efficiency of protein deposition [defined as (accretion/synthesis) $\mathrm{x} 100$ ] was lower in all selection lines than in controls $(0.44,0.38,0.40$ and 0.53 in DU-6P, DU-6, DU-6+LB and DU-Ks, respectively). Remarcable is the significant greater metabolic pool (P1) of the growth+fitness line (DU-6+LB) in comparison to the other selection lines. Because of identical half lives (T1/2) for the metabolic pool in all lines this suggests that the turnover of this line is more rapid than of the other lines. But this finding should be verified in further experiments.

\section{Muscle characteristics}

Changes in body composition and protein accretion were also reflected by results on muscle growth. Thereby it has to be considered that these mice were of a later age of postnatal life (60 days) and derived from a former gencration (68). As shown in Table 5, cross sectional arca of the EDL muscle was increased in all selection lines. Selection response tended to be higher in the protein line $(50 \%)$ and in the growth+fitness line (54\%) than in the growth line $(30 \%)$.

The increases in muscle girth were mainly realised by fibre hypertrophy in DU-6P and DU-6 mice. In DU-6+LB mice total fibre number and mean fibre size

TABLE 5

Body weight and histological muscle tibre characteristics of $M$. extensor digitorum longus (EDL) of micc sclected for different growth traits over 68 generations and of the control line at 60 days of age (LS means and SE)

\begin{tabular}{|c|c|c|c|c|}
\hline & $\begin{array}{l}\text { Control } \\
\text { DU-Ks }\end{array}$ & $\begin{array}{c}\text { Protein line } \\
\text { DU-6P }\end{array}$ & $\begin{array}{c}\text { Growth line } \\
\text { DU-6 }\end{array}$ & $\begin{array}{c}\text { Growth+litness line } \\
\text { DU-6+LB }\end{array}$ \\
\hline No. of animals & 10 & 12 & 10 & 7 \\
\hline Body weight, $g$ & $33.4 \pm 1.3^{a}$ & $56.7 \pm 1.2^{\mathrm{b}}$ & $64.1 \pm 1.3^{\circ}$ & $52.1 \pm 1.4^{d}$ \\
\hline Cross sectional area, $\mathrm{mm}^{2}$ & $1.31 \pm 0.11^{\mathrm{a}}$ & $1.97 \pm 0.11^{\mathrm{b}}$ & $1.70+0.11^{\mathrm{b}}$ & $2.02+0.13^{\mathrm{b}}$ \\
\hline Mean muscle fibre area, $\mu \mathrm{m}^{2}$ & $1270 \pm 87^{a}$ & $1621 \pm 76^{b}$ & $1537 \pm 87^{\mathrm{b}}$ & $1585 \pm 99^{b}$ \\
\hline Total muscle fibre number & $1058 \pm 61^{3}$ & $1238 \pm 56^{b}$ & $1124 \pm 61^{a b}$ & $1284 \pm 73^{b}$ \\
\hline Nuclei $/ \mathrm{mm}^{2}$ fibre area & $967 \pm 64^{a}$ & $727 \pm 61^{b}$ & $840 \pm 61^{3}$ & $847 \pm 79^{a}$ \\
\hline Nuclei/muscle cross section & $1155 \pm 104^{a}$ & $1348 \pm 90^{\mathrm{ab}}$ & $1507 \pm 99^{\circ}$ & $1599 \pm 128^{b}$ \\
\hline Capillaries/fibre & $0.34 \pm 0.03^{\mathfrak{a}}$ & $0.54 \pm 0.03^{b}$ & $0.47 \pm 0.04^{b}$ & $0.71 \pm 0.04^{c}$ \\
\hline Capillaries $/ \mathrm{mm}^{2}$ & $334.9 \pm 31.7^{a}$ & $390.2 \pm 28.9^{\circ}$ & $342.9+33.4^{\mathrm{a}}$ & $569.1+37.8^{\mathrm{b}}$ \\
\hline
\end{tabular}

a,b - significant differences between the groups are indicated by different letters $(P<0.05)$ 


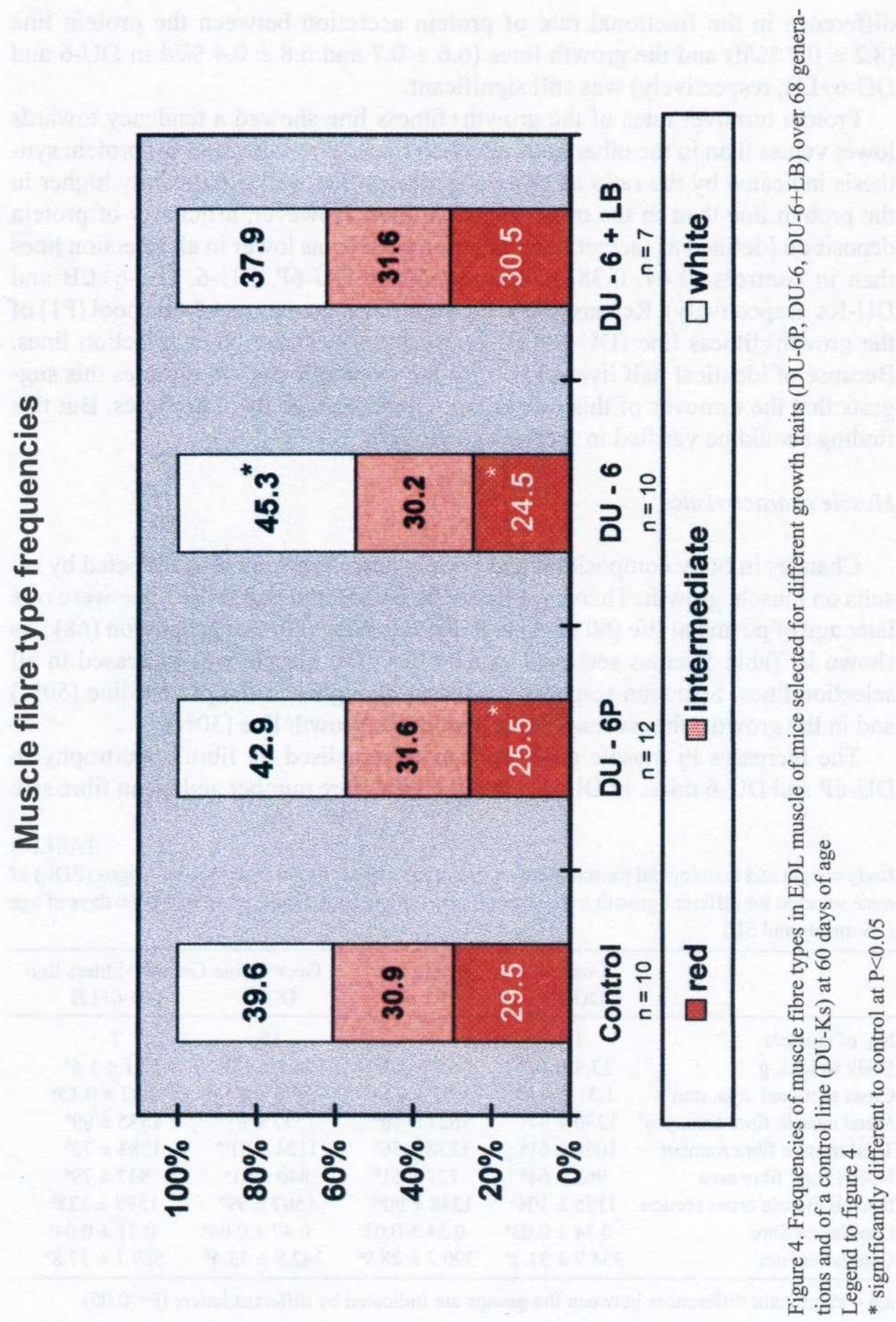


were increased by selection at almost the same extent. Increases in muscle size were accompanied by changes in myonuclear distribution. The total nuclear number per muscle cross section was more enhanced in the growth+fitness line $(38 \%)$ and in the growth line $(30 \%)$ as compared to the protein line $(17 \%)$. Because of the non-proportional increases in fibre size and nuclear number, the nuclear/cytoplasm ratio, measured as nuclear number $/ \mathrm{mm}^{2}$ fibre area, decreased significantly by selection (by $25 \%$ ) for protein mass. The data on blood capillary distribution as indicator for nutrient and oxygen supply revealed, that the number of capillaries was adequately increased with the enlargement of muscle cross section in the protein and growth line. However, in the growth+fitness line the number of capillaries per fibre was even doubled, and capillary density was enhanced by $70 \%$ in comparison to control line.

As shown in Figure 4 the distribution of metabolic muscle fibre types which indicates the main pathways of energy production was also influenced by longterm selection. The proportion of white (glycolytic) and intermediate fibres was significantly increased in the protein and growth line at the expense of red (oxidative) muscle fibres. Muscles of the growth+fitness line showed the highest red and the lowest white fibre proportions compared to all lines without significant differences to control.

\section{Blood hormones and $G L N$ content}

Although there were significantly different growth pattern in selected and unselected mice as well as between the selection lines plasma hormone concentrations were not clearly different (Table 6). At least this is in part caused by the immense variation between individuals (especially within the protein line) and by the small data base. Because of small blood sample volumes, it was not possible to

TABLE 6

Blood and tissue traits of mice selected for different growth parameters and of the control line at 33 days of age

\begin{tabular}{lcccc}
\hline Parameters/ Line & $\begin{array}{c}\text { Control } \\
\text { DU-Ks }\end{array}$ & $\begin{array}{c}\text { Protein line } \\
\text { DU-6P }\end{array}$ & $\begin{array}{c}\text { Growth line } \\
\text { DU-6 }\end{array}$ & $\begin{array}{c}\text { Growth+fitness linc } \\
\text { DU-6+LB }\end{array}$ \\
\hline $\mathrm{T}_{3}, \mathrm{nmol} / \mathrm{L}$ & $0.86 \pm 0.11^{\mathrm{a}}(7)$ & $0.88 \pm 0.15^{\mathrm{a}}(7)$ & $0.84 \pm 0.12^{\mathrm{a}}(9)$ & $0.84 \pm 0.24^{\mathrm{a}}(9)$ \\
$\mathrm{T}_{4}, \mathrm{nmol} / \mathrm{L}$ & $48.8 \pm 9.2^{\mathrm{a}}(7)$ & $38.8 \pm 10.8^{\mathrm{a}}(7)$ & $43.0 \pm 7.8^{\mathrm{a}}(9)$ & $42.7 \pm 10.7^{\mathrm{a}}(7)$ \\
$\mathrm{IGF}-\mathrm{I}, \mathrm{ng} / \mathrm{ml}$ & $446 \pm 51^{\mathrm{a}}(10)$ & $591 \pm 118^{\mathrm{b}}(9)$ & $610 \pm 96^{\mathrm{b}}(9)$ & $598 \pm 71^{\mathrm{b}}(12)$ \\
$\mathrm{GLN} \mathrm{content}$ in muscle extracts, & & & \\
$\mu \mathrm{mol} / \mathrm{g}$ muscle & $2.64 \pm 0.50^{\mathrm{a}}(12)$ & $2.82 \pm 0.63^{\mathrm{a}}(12)$ & $2.92 \pm 0.56^{\mathrm{a}}(11)$ & $2.06 \pm 0.89^{\mathrm{a}}(11)$ \\
\hline
\end{tabular}

values are means and SD. Number of animals in parantheses

a, $b$ - significant differences between the groups are indicated by different letters $(P<0.05)$

$\mathrm{T}_{3}=$ triiodothyronine; $\mathrm{T}_{4}=$ thyroxine; IGF-I= insulin-like growth factor-I; GLN= glutamine 
include all animals into the analyses. Neither the total $\mathrm{T}_{3}$ nor the total $\mathrm{T}_{4}$ levels in the blood were significantly different between the lines, but the IGF-I levels of selected mice were significantly higher than in controls. The free GLN content in muscle extracts was not significantly different between the lines because of high variation.

\section{DISCUSSION}

In this study we have investigated the influence of long-term selection for different growth traits on protein metabolism using a mouse model. The estimated fractional rates of the whole-body protein synthesis are comparable with those reported for $20 \mathrm{~g}$ mice by Garlick and Marshall (1972) and for $40 \mathrm{~g}$ mice by Waterlow et al. (1978) but are lower than values for normal $(31 \% / \mathrm{d})$ and fast growing (33\%/d) mice of the same age published by Bernier et al. (1987). Generally, all measurements on protein turnover in these lines were confirmed with a higher animal number (Schadereit et al., 1998). However, it should be noted, that the compartmental method used in the present studies includes some assumptions which are not completely valid leading to under- or overestimations of the absolute synthesis rates. Therefore the values can only be considered as an approximation allowing a relative comparison between the lines. The higher $\mathrm{N}$ accretion in the protein line (DU-6P) in comparison to the growth (DU-6) line seems to be due to a combination of enhanced protein synthesis and decreased protein breakdown. It can not be excluded that the approach was not sufficiently sensitive to elicit differences in protein synthesis between DU-6P and DU-6. The lower ratio of protein synthesis/protein accretion in the protein line in comparison to the growth line $(2.1$ and 2.5 , respectively) can be interpreted to indicate a lower protein breakdown rate in DU-6P mice. This assumption was evidenced by a significantly lower rate of $N^{1}$-methylhistidine excretion (index for the rate of myofibrillar protein degradation) observed in this line (Schadereit et al., 1998). The higher protein turnover level of selected mice at least in part may be caused by the increase of some visceral organs in response to enhanced food intakes of sclccted animals (see Figure 1), as the visceral organs contribute highly to whole body protein-synthesis (in micc $35 \%$; Bernier et al., 1987) which is not combined with protein deposition (Bergner, 1989; Simon, 1989). At the end of the metabolism experiment (33 d of age) the whole bodies of the selection lines had the same protein content, however, the body fat content in DU- 6 was enhanced by more than $60 \%$ and in DU- $6+$ LB by $11 \%$ compared to the protein line. The lean body of mice selected for an index combining body weight and endurance fitness (active type) compared to micc selected for body weight (inactive type) is consistent with results obtained in humans (Millward et al., 1994). 
Differences in protein accretion between the selection lines were also evident by muscle structure characteristics studied in a previous experiment and in older animals. As shown by histological data the enlargement of $E D L$ muscle cross sectional area was slightly lower after selection for body weight compared to selection for protein mass or for growth-fitness. Differences were also apparent at the cellular level. In the protein linc muscle nuclear/cytoplasm ratio declined markedly by selection (by $25 \%$ ) showing that protein accretion per nucleus was enhanced considerably. This effect was also found previously in EDL and rectus femoris muscles of mice in generation 43 of sclection and was also evident by lower DNA/ protein ratios (Rehfeldt and Bünger, 1990). The proliferative capacity of satellite cell indicated by myonuclear numbers was more enhanced by selection for body weight or for growth-fitness compared to selection for carcass protein content. Assuming that total fibre number is mainly a result of prenatal proliferation the overall proliferative capacity of muscle was mostly enhanced in the growth+fitness line. Moreover, the muscles of this line were characterised by enormous improvements of blood capillary supply and by fibre type frequencies indicating the oxidative pathway as major way for energy production. All these changes as well as the tendency towards lower glutamine levels of muscle extracts seem to meet the demands of high physical activity included into the selection index.

Taken together with previously obtained results (Rehfeldt and Bünger, 1990) selection for body weight or for protein mass changes the kinetics of postnatal fibre type conversion to a more glycolytic phenotype as also reporied by Swatland and Cassens (1972) on rats and by Nøstvold et al. (1979) on pigs. Extreme lean breeds of pigs (e.g. Pietrain), cattle and chickens exhibit relatively high white fibre percentages which correlate to the PSF (pale, soft, exudative) meat condition (Linke, 1972; Fiedler and Ender, 1984) and to stress-susceptibility in pigs (Fiedler et al., 1993).

The status of some growth-related hormones was characterized to examine whether there are selection-linked changes in relation to growth parameters. No significant differences in thyroid hormone levels $\left(\mathrm{T}_{3}, \mathrm{~T}_{4}\right)$ were observed between the lines. This confirms results on chickens divergently selected for body weight (Mc Nabb et al., 1989) where the circulating $T_{3}$ was not consistently higher in the growth-selected line or results of Lauterio et al. (1986), where circulating $T_{3}$ of growth-selected broiler strains was mostly higher than in controls while thyroxine levels did not differ at most posthatch stages. The failure in finding simple relations between the patterns of plasma $\mathrm{T}_{3}$ or $\mathrm{T}_{4}$ levels and the patterns of growth is explainable in the view of the complexity of thyroid hormone actions.

In our studies higher plasma IGF-I levels were found in all selected mice. There is considerable evidence of positive correlations between plasma IGF-I levels and improved nutrient supply in rats (Nam et al., 1990; Jahreis, 1993; Tomas and Pym, 1995; Tarim et al., 1997) and broiler chickens (Tomas et al., 1991), whereas no 
clear growth-related IGF-I pattern was observed in pigs ( Seve and Ponter, 1997) or broiler chickens (Mitchell and Burke, 1995) in which this relationship was lost at 28 days of age. Despite the very small data base per selection line relationships between IGF-I and growth parameters could be observed. Correlation coefficients calculated within each line did not reach statistical significance mainly due to the limited number of data points (7-12) and the high variation within the parameters. In all lines IGF-I levels were related to the daily $\mathrm{N}$ intake or $\mathrm{N}$ balance values $(r=0.62$ to $r=0.64$, respectively) and with the exception of index selected mice to the body weight ( $r=0.61$ to 0.77 ). Including all lines into this calculation the coherence was stronger. These findings are consistent with literature (Blair ct al., 1988; Bates and Pcll, 1991; Powell-Braxton et al., 1993) and the magnitude of the relation between body weight and IGF-I level equals to values given by Blair et al. (1987) who estimated correlation coefficients of $r=0.79$ in 35 day-mice and of $r=0.53$ in 110 -day mice. This shift to a stronger relation in young mice was supported by large scale studies by Souffrant and Kratzsch (personal communication). In all four mouse lines a further increase of the body weight was observed from day 42 of age onwards, but the plasma IGF-I levels dropped at this age. That means, moderate to strong phenotypic correlations can only be expected in young animals.

No clear relationships could be seen between plasma IGF-I values and protein synthesis in our mouse lines. This confirms results of Bates and Pell (1991) who did not find consistent positive correlations between the fractional rate of whole body or muscle protein synthesis and plasma IGF-I concentration in growth hormone $(\mathrm{GH})$ and/or clenbuterol treated dwarf mice. Interestingly, IGF-I levels parralled the increase in body weight only in $\mathrm{GH}$ or $\mathrm{GH}+\mathrm{clenbuterol}$ treated animals, but not after clenbuterol treatment alone. Also in pigs (Seve and Ponter, 1997), the mean absolute values of plasma IGF-I concentration could not explain betweengenotype differences in protein synthesis rates of different tissues. For example, Pietrain pigs had the lowest plasma IGF-I concentration and the highest muscle protein synthesis rate. From their studies with mice Sonntag et al. (1992) postulated that in normal aging animals the decrease in IGF-I is associated with the decline in protein synthesis, but that other regulatory mechanisms appear to have an important role in this process. In which way physiological variations in IGF-I level influence the protein turnover is not clear.

The muscle glutamine (GLN) content was not significantly different in the mouse lines and a moderate correlation to the protein synthesis of the whole body could only be seen in the index-selected growth line and in the protein line $(r=0.68$ and $r=0.56$, respectively). Highly correlated changes of both the protein synthesis and the GLN level in muscles were reported for rats (MacLennan et al., 1987; Jepson et al., 1988b) and for humans (Rennie et al., 1994). The nature of the mechanism and the physiological significance of the muscle GLN stores are not fully understood. 
The muscle GLN pool is thought to act as a labile store of nitrogen mobilized in times of stress (fasting, surgery, scpsis, cxogenous glucocorticoids and exercise) and the fall of intramuscular GLN content in the index-selected growth line may be caused by an enhanced demand for GLN of this line. The provision of exogenous GLN and the preservation of a high GLN pool may be related to the conservation of muscle protcin as cvidenced by studies in rats (Hickson et al., 1995). Current results (Rennie et al., 1996) suggest the possibility that GLN pool size is a part of an osmotic signalling mechanism to regulate whole body protein metabolism.

\section{CONCLUSIONS}

The experimental results on selection lines of mice show that nutrient partition and body composition were altered depending on the used selection traits. In mice selected for high body protein content, the higher protein deposition in the carcass is due to an improved efficiency of nitrogen utilization, a somewhat higher whole body protein synthesis combined with a slightly lower protein breakdown rate. Selection for body mass results in an increase of body fat, but not if combined with endurace fitness. Cellular structure of skeletal muscle is markedly changed by selection. The correlated selection response of skeletal muscle structure clearly differs in relation to selcction trait and is consistent with differences in body composition, protein metabolism and endurance fitness. IGF-I seems to be a significant determinant in realization of growth selection response.

\section{REFERENCES}

Bates P.C., Pell J.M., 1991. Action and interaction of growth hormone and the ß-agonist, clenbuterol, on growth, body composition and protein turnover in dwarf mice. Brit J. Nutr. 65, 115-129

Bergner H., 1989. N-Stoffwechsel und seine Regelmechanismen. Arch. Anim. Nutr. 39, 377-392

Bernier J.F., Calvert C.C., Baldwin R.L., 1987. Energetics of protein synthesis in mice with a major gene for growth. J. Nutr. 117, 2036-2045

Beyersdorfer G., Ohlerich M., Wegner J., 1985. Ein halbautomatisches Messgerät zur Morphometrie von Muskelfasem im mikroskopischen Querschnittspräparat. Z. mikr. anat. Forsch. 99, 671-675

Blair H.T., McCutcheon S.N., Mackenzie D.D.S., Gluckman P.D., Ormsby J.E., 1987. Variation in plasma concentration of insulin-like growth factor-I and its covariation with liveweight in mice. Aust. J. Biol. Sci. 40, 287-293

Blair H.T., McCutcheon S.N., Mackenzie D.D.S., Ormsby J.E., Siddiqui R.A., Breier B.H., Gluckman P.D., 1988. Genetic selection for insulin-like growth factor-I in growing mice is associated with altered growth. Endocrinology 123, 1690-1692

Bünger L., Remus N., Roschlau D., 1985. Selection for different growth parameters in laboratory mice and its correlated effects on body composition and organ weights. Nahrung 29, 549-560 
Bünger L., Renne U., Herrendörfer G., Sumpf D., Domröse H., Rehfeldt C., 1987, Langzeitsclektionsstrategie Wachstum und Bclastbarkeit. Anlage 2. F/E-Bcricht AdL der DDR, Research Centre of Animal l'roduction, Dummerstorf-Rostock

Fiedler I., Fnder K., 1984. Mikrostrukturmerkmale der Muskulatur in Beziehung zur Fleischbeschaffenheit beim Schwein. Tierzucht 38, 251-252

Fiedler I., Ender K., Wicke M., Lengerken von G., 1993. Zusammenhänge zwischen der Mikrostruktur des Muskelgewebes bei Schweinen der Landrasse und ihrer Stressempfindlichkeit (Halothanreaktion). Arch. Tierzucht 36, 525-538

Garlick P., Marshall J., 1972. A technique for measuring brain protein synthesis. J. Neurochem. 19, 577-583

Hickson R.C., Czerwinski S.M., Węgrzyn L.E., 1995. Glutamine prevents downregulation of myosin heavy chain synthesis and muscle atrophy from glucocorticoids. Amer. J. Physiol.-Endocrinol. Met. 31, E730-Г:734

Jahreis G., 1993. Insulinähnliche Wachstumsfaktoren und deren Bindungsproteine als Schaltstellen zwischen Ernährung und Wachstum. Übers. Tierernähr. 21, 55-86

Jepson M.M., Bates P.C., Broadbent P., Pell J.M., Millward D.J., 1988b. Relationship between glutamine concentration and protein synthesis in rat skeletal muscle. Amer. J. Physiol. 255, $166-172$

Jepson M.M., Bates P.C., Millward D.J., 1988a. The role of insulin and thyroid hormones in the regulation of muscle growth and protein turnover in response to dietary protein in the rat. Brit. J. Nutr. 59, 397-415

Krawielitzki K., Schadereit R., Wünsche J., 1989. Methodische Empfehlungen zur Bestimmung von Gesamtkörper-Proteinsyntheseraten im Tracerversuch. Arch. Anim. Nutr. (Berlin) 9, 799811

Lauterio T.J., Decuypere E., Scanes C.G., 1986. Growth, protein synthesis and plasma concentrations of growth hormone, thyroxine and triiodothyronine in dwarf, control and growth-selected strains of broiler-type domestic fowl. Comp. Biochem. Physiol. 83^, 627-632

Linke 11., 1972. I istologische Untersuchungen bei wässrigem, blassem Schweinefleisch. Fleischwirtschaft 52, 493-507

MacLennan P.A., Brown R.A., Rennie M.J., 1987. A positive relationship between protein synthetic rate and intracellular glutamine concentration in perfused rat skeletal muscle. FEBS Lett. 215, 187-191

Mc Nabb F.M.M., Dunnington E.A., Freeman T.B., Siegel P.B., 1989. Thyroid hormones and growth patterns of embryonic and posthatch chickens from lines selected for high and low juvenile body weight. Growth, Devclop. Aging 53, 87-92

Millward D.J., 1989. The nutritional regulation of muscle growth and protein turnover. Aquaculture $79,1-28$

Millward D.I., Bowtell J.L., Pacy P., Rennie M.J., 1994. Physical activity, protein metabolism and protein requirements. Proc. Nutr. Soc. 53, 223-240

Mitchell R.D., Burke W.H., 1995. Posthatching growth and pectoralis muscle development in broiler strain chickens, Bantam chickens and the reciprocal crosses between them. Growth, Develop. Aging 59, 149-161

Nam T.J., Noguchi T., Funabiki R., Kato II., Miura Y., Naito II., 1990. Correlation between the urinary excretion of acid-soluble peptides, fractional synthesis rate of whole body proteins, and plasma immunoreactive insulin-like growth factor-1/somatomedin $C$ concentration in the rat. Brit. J. Nutr. 63, 515-520

Naumann K., Bassler R., 1993. Methodenbuch. Band III. 3. Erg., Verlag J. Neumann, Neudamm, Melsungen 
Nøstvold O., Schie K. A., Frøystein T., 1979. Muscle fiber characteristics in lines of pigs selected for rate of gain and backfat thickness. Acta Agric. Scand., Suppl. 2I, 136-142

Novikoff A.B., Shin W., Drucker J., 1961. Mitochondrial localization of oxidative enzymes staining results with two tetrazolium salts. J. Biophys. Biochem. Cytol. 9, 47-61

Powell-Braxton L., Hollingshead P., Warburton C., Dowd M., Pitts-Meek S., Dalton D., Gillett N., Steward T.A., 1993. IGF-I is required for normal embryonic growth in mice. (iene. Develop. 7 , 2609-2617

Rasch D., Guiard V., Nürnberg G., Rudolph E., Teuscher E., 1987. Statistical Software Newslett. 13, 107

Rehfeldt Ch., Bünger L., Dietl G., Ender K., 1989. Zur Selektionswürdigkeit von Merkmalen der Muskulatur - Modellversuch mit Labormäusen. J. Anim. Breed Genet. 106, 208-216

Rehfeldt Ch., Bünger L., 1990. Auswirkungen einer Langzeitselektion von Labormäusen aul Merkmale des Muskelwachstums und der Muskelstruktur. Arch. Tierzucht 33, 507-516

Rennie M.J., Ahmed A., Khogali S., Low S.Y., Hundal H.S., Taylor P.M., 1996. Glutamine metabolism and transport in skeletal muscle and heart and their clinical relevance. J. Nutr. 126, 1142S$1149 \mathrm{~S}$

Rennie M.J., Tadros L., Khogali S.E.O., Ahmed A., Taylor P.M., 1994. Glutamine transport and its metabolic effects. J. Nutr. 124, 1503S-1508S

Romeis B., 1989. Mikroskopische Technik. Urban, Schwarzenberg (Editors). München, pp. 696

SAS Institute 1989-1996. The SAS System, Release 6.12. Cary, North Carolina, SAS Institute Inc.

Schadereit R., Klein M., Souffrant W., Krawielitzki K., Renne U., 1998. Protein metabolism in mice selected for high carcass protein content or high body weight. J. Anim. Physiol. Anim. Nutr. 78, 105-118

Schüler I., 1985. Der Mäusestamm Fzt:DU und seine Anwendung als Modell in der Tierzuchtforschung. Arch. Tierzucht 28, 357-363

Seve B., Ponter A.A., 1997. Nutrient-hormone signals regulating muscle protein turnover in pigs. Proc. Nutr. Soc. 56, 565-580

Simon O., 1989. Metabolism of protcins and amino acids. In: H.D. Bock, B.O. Eggum, A.G. Low, O. Simon, T. Zebrowska (Editors). Protein metabolism in farm animals. Evaluation, digestion, absorption and metabolism. Oxford Science Publications and VEB Deutscher Landwirtschaftsverlag, Oxford und Berlin, pp. 273-366

Sonntag W.E., Lcnham J.E., Ingram R.L., 1992. Effects of aging and dietary restriction on tissue protein synthesis: Relationship to plasma insulin-like growth factor-I. J. Gerontol. 47/5, B159-B163

Spannhof L., 1967. Einführung in die Praxis der Histochemie. VEB Gustav-Fischer-Verlag, Jena, pp. 172

Stat Soft Inc., 1995. Statistica for Windows, Release 5.0

Swatland H.J., Cassens R.G., 1972. A brief study of muscle enlargement in the rat. J. Anim. Sci. 34, 21-24

Tarim O., Chasalow F.I., Murphy J., Rising R., Carrillo A., Lifshitz F., 1997. Evaluation of differential effects of carbohydrate and fat intake on weight gain, serum IGT-1 and erythrocyte $\mathrm{Na}(+) \mathrm{K}(+)$ ATPase activity in suboptimal nutrition in rats. J. Amer. Coll. Nutr. 16, 159-165

Tomas F.M., Pym R.A., 1995. Muscle protein turnover and growth. Arch. Geflügclk. Sonderheft 23-26, OECD-Workshop, Ccllc, 1994

Tomas, F.M., Pym, R.A., Johnson, R.J., 1991. Muscle protein turnover in chicken selected for increased growth rate, food consumption or efficiency of food utilization: effects of genotype on relationship to plasma IGF-I and growth hormone. Brit. Poultry Sci. 32, 363-376

Waterlow J.C., Garlick P.C., Millward,D.C., 1978. Protein Turnover in Mammalian Tissues and in the Whole Body. Amsterdam, New York, Oxford, North-Holl. Publ. Comp., pp. 788 


\section{STRESZCZENIE}

\section{Wpływ kierunku selekcji na obrót bialka (protein turnover), sklad ciala, charakterystykę mięśni i hormony krwi u myszy}

Oznaczano obról białka w ciele oraz cechy tkanek u rosnących samców myszy z linii selekcjonowanych przez długi okres ( 78 pokoleń) na: zawartość białka w tuszy (DU-6P, linia „,białkowa”), masę ciała (DU-6, linia „wzrostowa”) lub wskażnik łączący masę ciała i wydajność ruchu na bieżni (DU-6 + LB, linia „wzrostowa” † „sprawnościowa”) oraz u kontrolnej grupy nieselekcjonowanej i kojarzonej losowo (DU-Ks). Dla oznaczenia obrotu białka szcść myšy z kał́dej linii utræymywano indywidualnie w klatkach pr¿emianowych i żywiono do woli przemysłową standardowa pasza (białko ogólne $268 \mathrm{~g}$, energia brutto $19 \mathrm{MJ} / \mathrm{kg}$ s.m.). Przy końcu doświadczenia masa ciała wszystkich wybranych myszy była około 2 razy więks7a nijz. kontrolnych. Czastkowe tempo syntezy białka (wyznaczonej w stosunku do ,puli” białka ciała) było istotnie większe u myszy selekcjonowanych niż kontrolnych, lec $<$ różniło się nicistotnie między liniami „białkową" i „w'zrostową" w przeciwieństwie do tempa odkładania białka. Skład chemiczny ciała zmieniał się w zależności od przyjętego kierunku selekcji. W ciele myszy linii „,wzrostowej” zawartość thuszczu była większa kosztem zawartości białka; w linii „białkowej” udział beztłuszczowej masy ciała (białko mięśni) był największy. Znajduje to potwierdzenie w wynikach wcześniejšego doświadczenia (68 pokoleń), przeprowadzonego na 60-cio dniowych myszach, u których stwierdzono zwiększenie powierzchni przekroju mięśnia extensor digitorum longus. Liczba naczyń włosowatych we włoknie mięśniowym, przyjęta jako wskaźnik zaopatrzenia mięśnia w składniki odżywcze i tlen, zwiększała się odpowiednio wraz ze zwiększaniem się powierzchni przekroju mięśnia u wszystkich selekcjonowanych linii, i była niemal dwukrotnie większa u myszy linii „wzrostowej” + „sprawnościowej”. Nie stwierdzono istotnych zmian w poziomie hormonów tarczycy $\left(\mathrm{T}_{3}, \mathrm{~T}_{4}\right)$ w krwi ani w zawartości wolnej glutaminy w miçśniach w zalcżności od kierunku selekcji. Poziom IGF-I w osočzu krwi był wyższy u myszy $z$ linii selekcjonowanych niż kontrolnych. 